\title{
Preface
}

\section{Palaeozoic geodynamics of the southwestern margin of Gondwana: controls on the present architecture of the Argentine-Chilean Andes}

\author{
F. Colombo ${ }^{1}$, J. García-Sansegundo², N. Heredia ${ }^{3}$ \\ ${ }^{1}$ Facultad de Geología, Universidad de Barcelona. C/ Martí i Franqués s/n, 08028 Barcelona, Spain. \\ ${ }^{2}$ Facultad de Geología, Universidad de Oviedo. C/ Jesús Arias de Velasco s/n, 33005 Oviedo, Spain. \\ ${ }^{3}$ Instituto Geológico y Minero de España (IGME). C/ Matemático Pedrayes 25, 33005 Oviedo, Spain.
}

e-mail addresses: colombo@ub.edu (F.C.); j.g.sansegundo@geol.uniovi.es (J.G.-S.); n.heredia@igme.es (N.H.)

Received: 17 March 2014 / Accepted: 25 May 2014 / Available online: 25 June 2014

The South American Pacific margin resulted from the alignment of the Andean Cordillera. The present architecture of the Andes is one of the best examples of mountain ranges associated with subduction, generated by the Andean Orogeny and developed along the Cenozoic.

During the Palaeozoic, the area of the present Andean Ranges and Antarctic Peninsula constituted one of the margins of Gondwana Continent, where a series of orogenic events controlled by the accretion of diverse lithospheric fragments occurred. The Late Palaeozoic underwent a series of subductive processes. The last continental collisions marked the transition to the present Andine Type Pacific margin.

The random distribution of the Palaeozoic outcrops along the Andean Ranges does not facilitate a coherent model of their geodynamic evolution. In some cases, the Palaeozoic events cannot be easily distinguished from those in the Andean cycle. For this reason, in the last six years, we developed the PaleoAndes I \& II projects (CGL2006-12415-CO3/ BTE and CGL2009-13706-CO3). These were supported by the Spanish I+D+i Plan and the FEDER Fund of the UE, in coordination with other Spanish projects, with the partial support of Argentinean and Chilean research funds. Within the framework of these projects, an international and multidisciplinary team of researchers from Spain, Argentina and Chile undertook the study of the Andean Cordillera, to the south of the $22^{\circ}$ of South Latitude. The principal aim was to study the geodynamic evolution of the proto-Andean Gondwana margin during this period, and this Special Volume contains the main results of both PaleoAndes projects.

For this Special Volume, the Palaeozoic history was grouped into five different orogenic cycles, which culmi- nate in the orogenies: Ross (Cambrian-Ordovician), Ocloyic (Ordovician-Devonian), Famatinian (Ordovician-Silurian), Chanic (Devonian-Carboniferous) and Gondwanan or San Rafael (Carboniferous-Permian). In each cycle, the preorogenic and synorogenic stages and the orogenic belt related to this last were also differentiated and characterized when possible. The Palaeozoic geodynamic processes were separated from those originated during the Andean cycle, highlighting if the recent Andean architecture retained some inheritances or have been conditioned by the Palaeozoic.

This Special Volume contains articles on magmatic, sedimentary, metamorphic and tectonic processes that occurred in the southwestern margin of Gondwana during the Palaeozoic and during its transit to the current South American margin.

The article by Hongn et al. (2014) (1 in Fig. 1A) presents the results of a study of the plutono-metamorphic dome of the Sierra de Cachi, located in the Eastern Cordillera of the Andes (Salta Province, Argentina). This dome is associated with the Ordovician extensional processes related to the Famatinian subduction, developed during the lower Palaeozoic on the western edge of Gondwana at this latitude. The plutonometamorphic extensional dome was subsequently deformed by the Ocloyic orogeny (Middle/Late Ordovician-Devonian).

Colombo et al. (2014) (2 in Fig. 1B) offer a characterisation of the synorogenic sedimentary rocks related to the Chanic (early Carboniferous) and Gondwanan (early Permian) orogenies, which are superimposed on the western edge of the Western Precordillera of San Juan Province (Argentina).

Gallastegui et al. (2014) (3 in Fig. 1B) deal with the petrology of the igneous clasts from the basal part of the Chanic synorogenic sequence "El Raton Formation" -also studied 


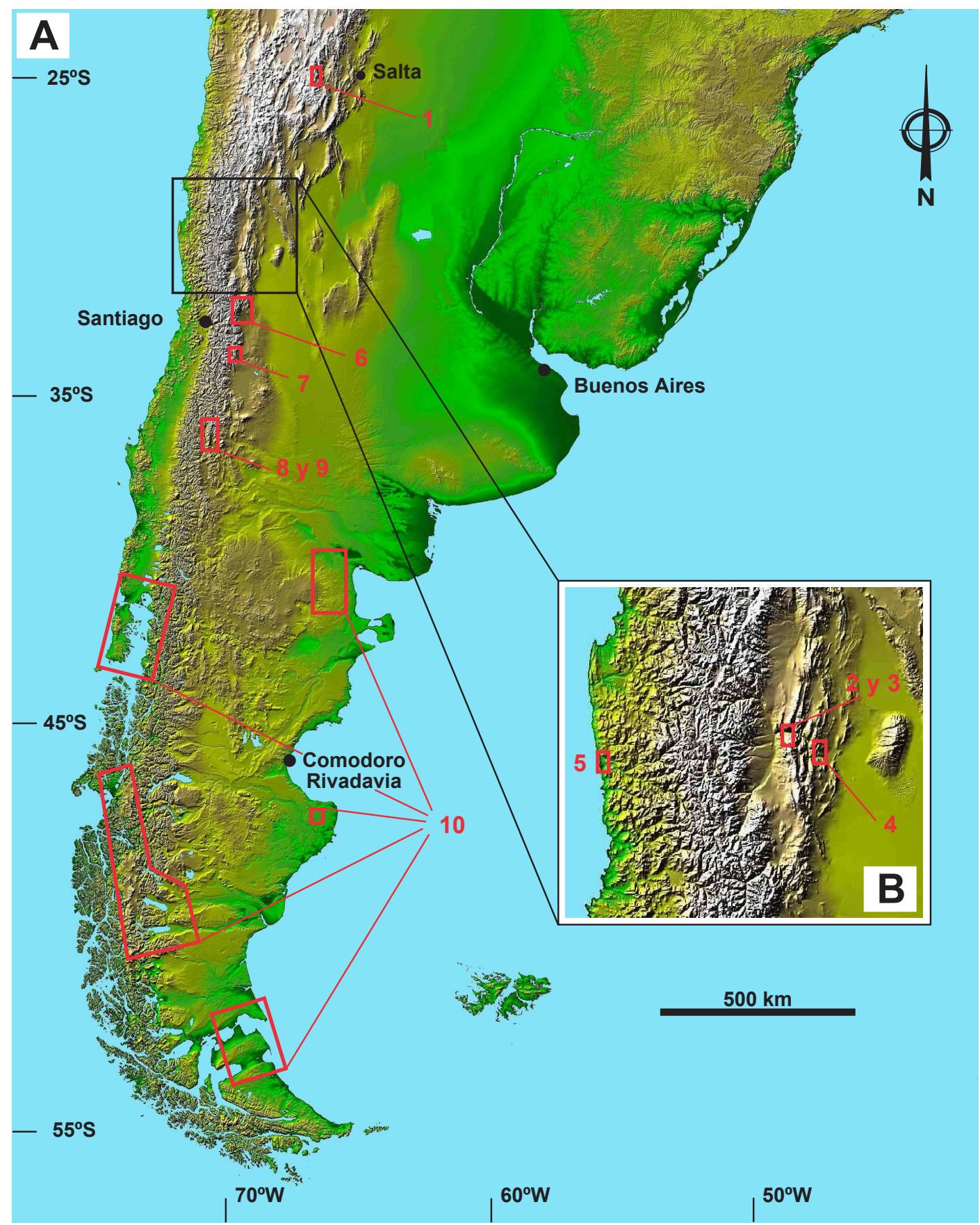

Fig. 1.- Location of the areas considered in this monographic volume. Base map taken from NASA Shuttle Radar Topography Mission (SRTM).

by Colombo et al in this volume- characterising the Chanic magmatism (pre-late Carboniferous) of the Frontal Cordillera. This work proposes changes in the source area of the synorogenic Chanic sediments in an attempt to account for the composition and distribution of the igneous clasts.

Alonso et al. (2014) (4 in Fig. 1B) consider the Punta Negra anticline related to the frontal Andean thrust of the Central Precordillera of Argentina (San Juan province) that affected earlier Palaeozoic thrusts of probably Gondwanan age. These authors also discuss the relationship between the formation of the anticline and the deposit of Cenozoic Andean synorogenic rocks.
García-Sansegundo et al. (2014a) (5 in Fig. 1B) characterise the metamorphism and structure of the Palaeozoic rocks on the Chilean coast, near Los Vilos $\left(30^{\circ} \mathrm{S}\right)$. These authors propose a geodynamic model for the Gondwanan cycle linked to a paleo-Pacific subduction that culminated in a noncollisional orogenic process in late Carboniferous-middle Permian times (San Rafael Orogeny).

Giambiagi et al. (2014) (6 in Fig. 1A) focus on the Chanic and Gondwanan deformations in the Frontal Cordillera and Southern Precordillera (Mendoza province of Argentina), with special emphasis on the control exerted by the Palaeozo- 
ic structures on the Andean ones during the Cenozoic. These authors also propose a new boundary for the Chilenia and Cuyania palaeo-continents, whose collision in Late Devonian times resulted in the Chanic orogeny.

García-Sansegundo et al. (2014b) (7 in Fig. 1B) provide a revealing insight into the Chanic and Gondwanan deformations in the Palaeozoic basement of the Carrizalito Range, located in the Frontal Cordillera of Mendoza (Argentina). These authors conclude that Chanic structures were generated in the inner part of the western branch of the Chanic orogen (Middle Devonian-early Carboniferous) along the eastern margin of Chilenia terrane.

Giacosa et al. (2014) (8 in Fig 1A) describe three different sequences of rocks in the Palaeozoic basement of the Cordillera del Viento (Neuquén province, Argentina) and separate the Chanic, Gondwanan, and Andean deformations. These authors propose a new geodynamic evolution for the Palaeozoic in the study area and also for the Central Andes between $28^{\circ}$ and $39^{\circ} \mathrm{SL}$, including the eastern areas affected by the Famatinian orogeny.

The article by Sagripanti et al. (2014) (9 in Fig. 1A), also located in the Cordillera del Viento, deals with the extension developed at the beginning of the Andean cycle (PermianTriassic), which is developed on compressive Gondwanan structures (late Carboniferous-early Permian). This study highlights the relationship between the extensional structures of the Triassic rift and the compressive Andean structures of the Agrio thrust and fold belt, using field and geophysical data.

Finally, Ramos and Naipauer (2014) (10 in Fig. 1A) discussed the presence of the Ross orogeny (Cambrian-Early Ordovician) in the eastern part of the Argentinean Patagonia. This orogeny was first defined in East Antarctica and probably resulted from its collision with Patagonia. This orogeny was followed by the rifting of Patagonia from Antarctica and by the initiation of a subduction along western Patagonia in Silurian-Devonian times. The final amalgamation of Patagonia with Western Gondwana took place in the late Palaeozoic (Gondwanan orogeny).

The results of some of these studies were presented at the Symposium: "Geology of the Andes and its foreland" during the VIII Spain Geological Congress (Oviedo-2012). The abstracts of this symposium are published in volume 13 of the Geo -Temas journal, a publication of the Geological Society of Spain (SGE).

\section{References}

Alonso, J.L., Gallastegui, G., Rodríguez Fernández, L.R., García-Sansegundo, J. (2014): Stratigraphy and structure of the Punta Negra Anticline. Implications on the structural evolution of the Argentine Precordillera. Journal of Iberian Geology 40 (2), 283-292. doi: 10.5209/ rev_JIGE.2014.v40.n2.45297

Colombo, F., Limarino, C.O., Spalletti, L.A., Busquets, P., Cardó, R., Méndez-Bedia, I., Heredia, N. (2014): Late Palaeozoic lithostratigraphy of the Andean Precordillera revisited (San Juan Province, Argentina). Journal of Iberian Geology 40 (2), 241-259. doi: 1010.5209/ rev JIGE.2014.v40.n2.45311

Gallastegui, G., González-Menéndez, L., Rubio-Ordóñez, A., Cuesta, A., Gerdes, A. (2014): Origin and provenance of igneous clasts from late Palaeozoic conglomerate formations (Del Ratón and El Planchón) in the Andean Precordillera of San Juan, Argentina. Journal of Iberian Geology 40 (2), 261-282. doi: org/10.5209/rev_JIGE.2014.v40. n2.45298

García-Sansegundo, J., Farias, P., Heredia, N., Gallastegui, G., Charrier, R., Rubio-Ordóñez, A., Cuesta, A. (2014a): Structure of the Andean Palaeozoic basement in the Chilean coast at $31^{\circ} 30^{\prime} \mathrm{S}$ : Geodynamic evolution of a subduction margin. Journal of Iberian Geology 40 (2), 293-308. doi: 10.5209/rev JIGE.2014.v40.n2.45300

García-Sansegundo, J., Farias, P., Rubio-Ordóñez, A., Heredia, N. (2014b): The Palaeozoic basement of the Andean Frontal Cordillera at $34^{\circ} \mathrm{S}$ (Cordón del Carrizalito, Mendoza Province, Argentina): Geotectonic implications. Journal of Iberian Geology 40 (2), 321-330. doi: 10.5209/rev_JIGE.2014.v40.n2.45299

Giacosa, R., Allard, J., Foix, N., Heredia, N. (2014): Stratigraphy, structure and geodynamic evolution of the Paleozoic rocks in the Cordillera del Viento ( $37^{\circ} \mathrm{S}$ latitude, Andes of Neuquén, Argentina). Journal of Iberian Geology 40 (2), 331-348. doi: 10.5209/rev_JIGE.2014.v40. n2.45301

Giambiagi, L., Mescua, J., Heredia, N., Farías, P., García Sansegundo, J., Fernández, C., Stier, S., Pérez, D., Bechis, F., Moreiras, S.M., Lossada, A. (2014): Reactivation of Paleozoic structures during Cenozoic deformation in the Cordón del Plata and Southern Precordillera ranges (Mendoza, Argentina). Journal of Iberian Geology 40 (2), 309-320. doi: 10.5209/rev_JIGE.2014.v40.n2.45302

Hongn, F.D., Tubía, J. M. Esteban, J.J., Aranguren, A., Vegas, N., Sergeev, S., Larionov, A., Basei, M. (2014): The Sierra de Cachi (Salta, NW Argentina): geological evidence about a Famatinian retro-arc at mid crustal levels. Journal of Iberian Geology 40 (2), 225-240. doi: org/10.5209/rev_JIGE.2014.v40.n2.45303

Ramos, V.A., Naipauer, M. (2014): Patagonia: where does it come from? Journal of Iberian Geology 40 (2), 367-379. doi: 10.5209/ rev JIGE.2014.v40.n2.45304

Sagripanti, L., Folguera, A., Giménez, M., Rojas Vera, E. A., Fabiano, J.J., Molnar, N., Fennell, L., Ramos, V.A. (2014): Geometry of Middle to Late Triassic extensional deformation pattern in the Cordillera del Viento (Southern Central Andes): A combined field and geophysical study. Journal of Iberian Geology 40 (2), 349-366. doi: 10.5209/ rev_JIGE.2014.v40.n2.45305 